\title{
DZIALALNOŚĆ GOSPODARCZA I FUNDACYJNA KASZTELANA KRAKOWSKIEGO JANA Z PILCZY (OK. 1405-1476). CHARAKTERYSTYKA NA TLE DZIEJÓW AKTYWNOŚCI WYBRANYCH PRZEDSTAWICIELI STRONNICTWA IUNIORES
}

Historia aktywności nieformalnych frakcji możnowładczych stanowi jeden z istotniejszych czynników kształtujących obraz politycznych dziejów Korony Królestwa Polskiego. W kontekście badań nad epoką wieków średnich godną uwagi historyków pozostaje m.in. kwestia rywalizacji grupy zwolenników biskupa Zbigniewa Oleśnickiego z frakcją możnowładców, tworzoną przez konfederatów Spytka z Melsztyna z 1439 r., którzy za sprawą Jana Długosza zapamiętani zostali jako juniorzy. Podejmując próbę scharakteryzowania dziejów stronnictwa iuniores, warto, poza kwestiami politycznymi, podjąć także problem sytuacji i działalności gospodarczej jego członków. Analiza tych dziedzin życia jest kluczowym czynnikiem poznania pozycji, jaką zajmowali przedstawiciele dawnego obozu młodoszlacheckiego w społeczeństwie Korony Królestwa Polskiego w piętnastym stuleciu. Mimo, iż status materialny poszczególnych reprezentantów tej grupy był w znaczny sposób zróżnicowany, to jednak można pokusić się o spojrzenie syntetyczne i poczynienie obserwacji, które okazują się w pewnym zakresie wspólne dla głównego trzonu stronnictwa iuniores. Istotną gałęzią działalności późnośredniowiecznego możnowładztwa bez wątpienia pozostawała również ta o charakterze fundacyjnym. Rozważania wokół tego zagadnienia są nieodłącznym elementem badań prozopograficznych. Nie można więc bagatelizować tej sfery życia szlacheckiego, usiłując przysłonić ją w biografiach aktywnością polityczną. Nie należy też podejmować prób konstruowania obrazu stronnictwa iuniores bez ogólnego spojrzenia na najważniejsze fundacje, których autorami byli jego członkowie.

Niestety brak we współczesnych opracowaniach na temat dziejów możnowładztwa z kręgu iuniores syntezy dotyczącej ogólnej charakterystyki działalności gospodarczej i fundacyjnej członków stronnictwa ${ }^{1}$. W tym kontekście cenną może okazać się więc próba konfrontacji tego rodzaju aktywności, podejmowanej przez jednego z juniorów, z ogólną charakterystyką działalności wybranych przedstawicieli stronnictwa. Postacią w tym kontekście reprezentatywną, jednak ciągle rzadko obecną w opracowaniach na temat polskiego

\footnotetext{
1 Wśród nowszych opracowań na temat dziejów stronnictwa iuniores warto zwrócić uwagę na artykuł J. Sperka, B. Czwojdrak, Konfederaci Spytka z Melsztyna z roku 1439, w: Króla a prawo stanów do oporu, red. M. Markiewicz, E. Opaliński, R. Skowron, Kraków 2010 s. 89-104.
} 
możnowładztwa w XV wieku, był kasztelan krakowski Jan z Pilczy. Jego sylwetka stanowi jeden z wyraźniejszych przykładów awansu społeczno-politycznego członków iuniores w okresie panowania królów Władysława III i Kazimierza Jagiellończyka. Adwersarz polityczny biskupa Zbigniewa Oleśnickiego, sygnatariusz aktu konfederacji Spytka z Melsztyna z 1439 r., syn królowej Elżbiety Granowskiej, zajmujący w swej karierze najwyższe urzędy w Koronie, wydaje się być dobrym przykładem małopolskiego możnowładcy z kręgu młodoszlacheckiego, który wypełniając program polityczny stronnictwa iuniores, wszedł do kręgu najbliższych współpracowników władcy. Na tej podstawie warto bliżej przyjrzeć się dziejom jego działalności gospodarczej i fundacyjnej oraz podjąć próbę odniesienia wyników poczynionych obserwacji do obrazu aktywności innych juniorów.

Już sama geneza obozu iuniores, którego członkiem był Jan z Pilczy, opiera się w pewnej mierze o czynniki gospodarcze. Młodzi członkowie zasłużonych, często bardzo zamożnych rodów Korony, odsuwani od wpływów w państwie wraz z umacnianiem się pozycji politycznej biskupa Oleśnickiego, poczęli z czasem odczuwać pogorszenie swojej sytuacji materialnej². Wynikało to między innymi z częściowego ograniczania ich majątków ziemskich, jak miało to miejsce w przypadku Spytka z Melsztyna ${ }^{3}$. Wraz z rozwojem tego zjawiska, w sposób drastyczny obniżał się poziom dochodów poszkodowanych polityką Oleśnickiego. Frustrację i ograniczenie zysków finansowych powodowało także odsunięcie juniorów od ścieżek awansu do wyższych urzędów ziemskich i centralnych, które piastowali niegdyś ich ojcowie i dziadowie. Oba czynniki wiązały się z powolnym zubażaniem tej części szlachty. Jej działalność opierać mogła się jedynie o rodowe dobra ziemskie, nie zawsze przynoszące dochody na oczekiwanym poziomie.

Wraz ze wstąpieniem na tron polski Władysława III nastąpił powolny wzrost znaczenia politycznego iuniores. Poprawiać poczęła się także ich sytuacja majątkowa, która pozwalała na rozwijanie działalności gospodarczej. Najlepiej widoczne umocnienie pozycji dawnych juniorów nastąpiło natomiast po przyjęciu korony polskiej przez Kazimierza Jagiellończyka ${ }^{4}$. Dzięki szerokim nadaniom na rzecz królewskich sojuszników, oprócz wpływów politycznych, rosły także ich dochody. Nierzadkim zjawiskiem stało się za czasów Kazimierza oddawanie w zarząd królewszczyzn, które także generowały spory przychód. Mimo tego główną osią działalności gospodarczej pozostały dla wschodzącej grupy możnowładców ich dobra rodzinne. W oparciu o ich otoczenie prowadzili oni akcję kolonizacyjną, lokując miasta i wsie związane stosunkami służebnymi.

Również działalność gospodarcza Jana z Pilczy opierała się w dużym stopniu na dochodach płynących z jego dóbr. Zaliczyć do nich można przede wszystkim majątki w ziemi przemyskiej tj. Łańcut, Kańczugę, klucz tyczyński oraz dobra klucza pilickiego z miastem Pilicą na czele. Ten ostatni, od którego ród Pileckich wziął swe nazwisko, obejmował zamek w Smoleniu, Starą Pilicę, Nową Pilicę, Bydlin oraz około 20 wsi wraz z folwarkami. Klucz tyczyński obejmował poza samym Tyczynem około 18 wsi. Dobra łańcuckie i kańczuckie razem stanowiły zaś około

\footnotetext{
2 Zob. A. Sochacka, Konfederacja Spytka z Melsztyna z 1439 r. - rozgrywka polityczna czy ruch ideologiczny?, „Rocznik Lubelski”, 16, Lublin 1973, s. 41-66.

3 W. Dworzaczek, Leliwici Tarnowscy. Z dziejów możnowładztwa małopolskiego wiek XIV-XV, Warszawa 1971, s. 141.

4 Zob. W. Fałkowski, Elita władzy w Polsce za panowania Kazimierza Jagiellończyka (1447-1492), Warszawa 1992.
} 
$20 \mathrm{wsi}^{5}$. Sam więc stan posiadania tak dużej, jak na ówczesne warunki, liczby dóbr ziemskich stawiał Pileckiego w szeregu ludzi stosunkowo zamożnych. Daje to powód do refleksji nad sposobem zarządzania ów dobrami pod względem gospodarczym. Uprawnione także staje się w tym kontekście porównanie działań, jakie podejmował w tym zakresie kasztelan Jan z Pilczy, do pewnego modelu przedsięwzięć członków dawnego stronnictwa młodoszlacheckiego.

Mimo, iż nie było w czasach działalności Jana z Pilczy realnej możliwości uzyskania przywileju ordynacyjnego, warto zauważyć, że próbował on konsolidować swoje majątki. Widać to dobrze na przykładzie Tyczyna, który dzięki staraniom Pileckiego, z czasem zaczęto zaliczać do kręgu ziemi przemyskiej, w której znajdował się szereg miejscowości pozostających jego własnością ${ }^{6}$ W wyniku małżeństwa z Jadwigą Kurowską i podziału spadku po śmierci swego teścia, Piotra, Jan wszedł także w posiadanie części Kurowa, Krzczonowa i Rzemienowic, znajdujących się w ziemi wiślickiej . O skali aktywności gospodarczej Pileckiego świadczą również zestawienia wierzytelności. Przykładowo, w ziemi przemyskiej Jan z Pilczy w połowie XV stulecia był najwyżej zadłużonym właścicielem ziemskim $^{8}$. Zaciąganie kredytów i udzielanie pożyczek było Pileckiemu potrzebne do rozwoju działań zarówno politycznych, jak gospodarczych. O jego umiejętnościach i swobodzie w obracaniu kapitałem świadczy fakt, iż Jan z Pilczy był jednym z głównych powierników i pożyczkodawców króla Kazimierza Jagiellończyka, a wcześniej Władysława III. Kontakty finansowe budowały dobre relacje z władcą, czego dowodem może być królewski dokument zwalniający Jana z Pilczy z poręczenia w wysokości 753 florenów, jakiego udzielił on za monarchę wojewodzie lwowskiemu, Piotrowi Odrowążowi ${ }^{9}$. W obrocie kredytami Pilecki korzystał z usług krakowskich rodzin mieszczańskich. Dla przykładu warto przytoczyć pożyczkę w wysokości 2000 węgierskich florenów, której udzielił Pilecki królowi w 1461 roku. Dokonał tego przy pomocy rodziny Morsztynów, pozostającej wówczas dzierżawcą żup solnych $^{10}$. Aktywność iuniores wokół wydobycia soli wydaje się być symptomatyczną. Potwierdzać może to choćby wspólna inicjatywa udzielenia poparcia finansowego żupnikowi Mikołajowi Serafinowi przez Andrzeja Tęczyńskiego, Jana Czyżowskiego oraz Jana Koniecpolskiego. Juniorzy kierowali się w tym przypadku najpewniej chęcią powstrzymania rosnącej konkurencyjności soli importowanej do Korony z terenów Państwa Zakonnego ${ }^{11}$. Na uwagę zasługuje fakt, iż możnowładcy którzy często znacząco różnili się poglądami w kwestiach polityki wewnętrznej, potrafili podjąć wspólne działanie nie tylko korzystne dla ich samych, ale także pożyteczne dla interesu państwa. Sam Tęczyński stał się z czasem posiadaczem praw górniczych, które upoważniały go do partycypacji w dochodach z eks-

\footnotetext{
E. Wac, Kilka uwag o działalności gospodarczej panów z Pilicy w XIV-XVI wieku, „Annales Academiae Paedagogicae Cracoviensis. Studia Historica”, 3/2004, Kraków 2004, s. 479; F. Kiryk, S. Matuszew, Zarys dziejów Tyczyna do roku 1772, w: 600 lat Tyczyna (1368-1968), red. T. Kowalski, Rzeszów 1973, s. 113.

6 Tamże, s. 45-60.

7 Joannis Dlugosz senioris canonici cracoviensis - Liber Beneficiorum diocesis cracoviensis, t. 1, wyd. A. Przeździecki, Kraków 1863, s. 53.

8 M. Ungeheuer, Stosunki kredytowe w ziemi przemyskiej w połowie XV wieku, Lwów 1929, s. 198.

9 Zbiór dokumentów małopolskich (dalej ZDM), 5, wyd. S. Kuraś, Wrocław 1970, nr 1465.

10 Matricularum Regni Poloniae Summaria (dalej MRPS), 1, wyd. T. Wierzbowski, Warszawa 1905, nr 578; S. Krzyżanowski, Morsztynowie w XV wieku, „Rocznik Krakowski”, t, 1, Kraków 1898, s. 326-358; J. Piotrowicz, Rozwój żup krakowskich w średniowieczu, w: Dzieje żup krakowskich, red. R. Kędra, Wieliczka 1988, s. 142-143.

11 S. Gawęda, Możnowładztwo małopolskie w XIV i w pierwszej połowie XV wieku: Studium z dziejów rozwoju wielkiej własności ziemskiej, Kraków 1966, s. 108.
} 
ploatacji wspomnianych żup solnych, których działalność rozwijał za sprawą usprawniania wydobycia $^{12}$. Jednym z dzierżawców żup stał się w 1459 roku także Hińcza z Rogowa, który swymi działaniami zapobiegał pogłębiającemu się kryzysowi w sferze obrotu solą ${ }^{13}$.

W zarządzaniu swymi dobrami Jan z Pilczy zwracał uwagę m.in. na handel, który starał się rozwijać, uzyskując kolejne przywileje organizowania jarmarków w jego miastach. Najbardziej reprezentatywnymi przykładami są w tym przypadku przywileje dla Tyczyna i Łańcuta. Pierwszy z nich, uzyskany 14 sierpnia 1447 r., określał termin tyczyńskiego targu na święto Bożego Ciała ${ }^{14}$. Zapisy dokumentu pozwalały m.in. na udział w targu wielu rodzajom kupców ${ }^{15}$. Taki stosunek do kwestii uregulowań handlowych otwierał przed miastem drogę do szybkiego rozwoju. Przywilej łańcucki Jan z Pilczy uzyskał natomiast 24 czerwca 1448 roku podczas zjazdu w Lublinie. Ustalał on coroczny targ w Łańcucie na tydzień przed dniem świętego Wojciecha ${ }^{16}$. Podobny przywilej, wpisany do metryki koronnej, Pilecki uzyskał także dla Kańczugi w roku $1473^{17}$. Świadczyć może to o trosce Jana z Pilczy o odpowiednie zabezpieczenie gospodarcze dla swych posiadłości. Dzięki zapisom przywilejów dla jego miejscowości wiadomo także, iż Pilecki, nie ograniczając osadnictwa obcego w swych miastach i wsiach, przyczyniał się do rozwoju w nich handlu.

Jan z Pilczy dużo uwagi poświęcał kwestii przemysłu w postaci górnictwa i wyrobu żelaza. Warto uświadomić sobie, iż obecność i funkcjonowanie kopalń w danym regionie miały wpływ na jego ogólny stan gospodarczy i przyczyniały się do rozwoju regionu. Do Pileckiego należały między innymi dwie kuźnie wytapiające żelazo we wsiach Blanowice - w okolicach Zawiercia oraz Krzemienida - koło Siewierza, a także kopalnie ołowiu w Strzegowej i Złożeńcu ${ }^{18}$. Te, rozwijające się wówczas, gałęzie gospodarki miały bezpośredni wpływ na poziom obronności Korony. Słusznym zatem wydaje się być stwierdzenie, iż poprzez odpowiednie zarządzanie tymi obiektami, Jan z Pilczy przyczyniał się do poprawy sytuacji wewnętrznej państwa, oddając mu swój możnowładczy obowiązek.

Wraz z poprawą swej pozycji politycznej, również inni członkowie stronnictwa juniorów poczęli odbudowywać także status materialny swych rodów. Majątek członków iuniores, poza częściami dziedzicznymi, opierał się m.in. na nadaniach z tenut starościńskich. Przykładem tego może być działalność Dziersława Rytwiańskiego, któremu ogromne zyski przynosiło do 1477 r. starostwo sandomierskie ${ }^{19}$. Znaczne dochody z tenuty chęcińskiej i zwoleńskiej czerpał Hińcza z Rogowa ${ }^{20}$, natomiast Mikołajowi z Brzezia zysk przynosiło starostwo dobczyckie ${ }^{21}$.

12 Tamże, s. 107.

13 J. Piotrowicz, dz. cyt., s. 145.

14 MRPS, 1, Warszawa 1905, nr 5; Słownik historyczno-geograficzny ziemi sanockiej w średniowieczu, cz. 3, opr.

A. Festnacht, Kraków 2002, s. 200.

15 Matricularum Regni Poloniae Codices Saeculo XV Conscripti, 1, wyd. W. Graniczny, A. Mysłowski, Warszawa 1914, nr 33.

16 MRPS, 1, Warszawa 1905, nr 18.

17 Tamże, nr 973.

18 E. Wac, dz. cyt., s. 479.

19 B. Czwojdrak, Jastrzębce w ziemi krakowskiej i sandomierskiej do połowy XV wieku, Kraków 2007, s. 120-121; J. Wroniszewski, Tenuty i tenutariusze w średniowiecznym województwie sandomierskim, w: Dwór a kraj. Między centrum a peryferiami władzy, red. R. Skowron, Kraków 2003, s. 56.

20 Tamże, s. 50.

21 F. Kiryk, Lanckoroński Mikołaj h. Zadora (zm. 1462), Polski Słownik Biograficzny, t. 16, Wrocław Warszawa Kraków Gdańsk, 1971, s. 446. 
Przykłady te wzmacniają wniosek na temat istnienia ścisłego związku pomiędzy rozwojem kariery politycznej i działalnością ekonomiczno-gospodarczą możnowładców w późnym średniowieczu. Wraz ze wzrostem majątków iuniores, rosła także liczba zamków prywatnych, budowanych zarówno jako rezydencje rodzinne, jak i warownie obronne. W odniesieniu do działalności członków obozu młodoszlacheckiego, proces ten osiągnął swoje apogeum po objęciu tronu przez Kazimierza Jagiellończyka. Władca z aprobatą odnosił się wówczas do planów budowania nowych i modernizowania istniejących już zamków, zwłaszcza tych zlokalizowanych w pobliżu granic państwa ${ }^{22}$. Przykładem z kręgu iuniores może być w tym przypadku rodzina Kmitów i ich zamki w Wiśniczu i Sobieniu ${ }^{23}$.

Ważnym czynnikiem wpływającym na sytuację szlachty w wymiarze ogólnym, a zatem także na przedstawicieli obozu młodoszlacheckiego, były w omawianym czasie majątkowe nadania królewskie. Dowodem tego rodzaju relacji finansowej pomiędzy królem a Janem z Pilczy były zapisy na jego dobrach. Przykładem może być dokonany przez Kazimierza Jagiellończyka w 1473 r., zapis 40 florenów węgierskich na ziemiach zamszańskich, należących do Pileckiego ${ }^{24}$. Warto odnotować w tym miejscu, iż do połowy stulecia nie można mówić o faworyzowaniu przez monarchów ani wyróżnianiu juniorów w tej kwestii. Dla zobrazowania tego zjawiska warto przytoczyć dwa przykłady. Do 1450 r. pełniący za panowania Kazimierza Jagiellończyka wysokie urzędy państwowe, Mikołaj Lanckoroński z Brzezia wraz ze swym bratem Janem, otrzymali jako nadania królewskie tylko jeden zamek, jedno miasto i 11 wsi. Należący do najważniejszych postaci z kręgu stronnictwa juniorów, współtworzący następnie obóz królewski, Dziersław z Rytwian nie otrzymał w tym samym czasie żadnego nadania, posiadając jednak pokaźną liczbę $41 \mathrm{wsi}^{25}$. Dużo więcej uwagi juniorzy poświęcali rozwojowi swych majątków rodowych i znajdujących się na ich terenie miast. Jednym ze sposobów zapewnienia wzrostu gospodarczego danemu ośrodkowi było nadawanie prawa niemieckiego. Od zabiegu tego nie stronili także członkowie obozu młodoszlacheckiego. Przykładem może być w tym przypadku Piotr z Kurowa, który w 1442 r. nadał nowoczesne prawo miejskie Bochotnicy ${ }^{26}$.

Ten krótki rys obrazuje szerokie spektrum działalności gospodarczej iuniores. W omawianym przypadku na uwagę zasługuje zróżnicowany charakter podejmowanych działań. Poza rozwojem dóbr już posiadanych, juniorzy w dużej mierze zabiegali także o poszerzanie swych majątków, wykazując się przy tym niewątpliwą ambicją. Jednocześnie nie odwracali też swej uwagi od istotnych dla Korony kwestii ogólnogospodarczych, takich jak wydobycie soli.

Jako majętny członek stanu szlacheckiego pełniący w ciągu swego życia najwyższe godności państwowe, Jan z Pilczy skupiał swą uwagę także na działalności fundacyjnej. Dotyczyła ona głównie terenów będących jego własnością, co nie stanowiło jednak reguły. Spojrzenie na najważniejsze przykłady fundacji Pileckiego wydaje się być zatem zagadnieniem kluczowym dla budowy pełnego obrazu tej postaci. Zabieg ten ułatwia dostrzeżenie programu i postawy ideowej oraz religijnej, jaką prezentował Jan z Pilczy, a także pozwala zbliżyć się do poznania

22 S. Gawęda, Możnowładztwo małopolskie..., s. 117.

23 Tamże, s. 118; R. Trawka, Kmitowie. Studium kariery politycznej i społecznej w późnośredniowiecznej Polsce, Kraków 2005, s. 141-145.

24 P. Węcowski, Mazowsze w Koronie. Propaganda i legitymizacja władzy Kazimierza Jagiellończyka na Mazow$s z u$, Kraków 2004, s. 72.

25 S. Gawęda, dz. cyt., s. 105.

26 ZDM, 3, nr 593. 
jego stosunku do kultury i nauki. Są to kwestie fundamentalne i niezbędne dla właściwego zrozumienia mentalności reprezentantów poźnośredniowiecznego, polskiego możnowładztwa.

Najwcześniejszą w tej dziedzinie aktywnością Jana z Pilczy było potwierdzenie 6 października 1426 r. fundacji ołtarza świętej Elżbiety w kaplicy Najświętszej Marii Panny Katedry Krakowskiej, dokonanej przez królową Elżbietę Granowską. Kontynuując dzieło swej matki, Jan uposażył ołtarz stałym dochodem 12 grzywien, pochodzących z czynszu ze wsi Branice ${ }^{27}$. Miało to zapewnić środki na utrzymanie ołtarza. Całe przedsięwzięcie może świadczyć o dużym przywiązaniu Pileckiego do matki i zachowaniu szacunku dla jej decyzji, nawet po jej śmierci. Fundacja ołtarza w stołecznej katedrze miała także charakter prestiżowy, dzięki czemu dwudziestoletni wówczas Jan mógł dać się poznać swemu środowisku jako odpowiedzialny i hojny pan, przywiązany do swych tradycji rodowych.

Kolejną fundacją pośrednią, również kościelną, poczynioną przez Jana wspólnie ze swą siostrą - Elżbietą, było doprowadzenie do podniesienia w roku 1432 rangi kościoła pilickiego z probostwa do prepozytury. Formalnie aktu tego dokonał biskup krakowski Zbigniew Oleśnicki, jednak wiadomo, iż stało się to na skutek zabiegów rodzeństwa z Pilicy ${ }^{28}$. Jan i Elżbieta zadbali wówczas o bogate uposażenie kościoła. Na jego potrzeby przeznaczone zostały dochody z dziesięciny ze wsi Domanowice, a także te pobierane od załęskich chłopów i z pól pilickiego dworu. Wikariusze otrzymywali również połowę z dziesięciny od łośnickich kmieci i 14 grzywien srebra na rok od stanu mieszczańskiego miasta Pilica. Nowopiliccy rzeźnicy mieli natomiast przekazywać im rocznie 2 kamienie łoju. Listę źródeł dóbr, stanowiących uposażenie prepozytury pilickiej, zamykają ofiary pochodzące z kościoła, a także dobra nieruchome, na które składały się dom i 4 ogrody. Dokument biskupa Oleśnickiego określa także dochody samego prepozyta, które stanowiły sumę dziesięciny snopowej z sołectwa Sławnowo, dziesięciny zebranej od zagrodników staropilickich, dziesięciny z Dłużca, Lgoty, Wolbromia (dobro królewskie), dziesięciny polnej od mieszczan z Bydlina, Kąpieli, Przyłubska i Żedowa oraz, tak jak w wypadku wikariuszy, z pilickich pól dworskich. Na uposażenie prepozyta składały się ponadto ofiary z kolędy, prowadzonej na terenie parafii, jedna trzecia sumy ofiar składanych w kościele i 6 kamieni łoju, ofiarowywanych przez pilickich rzeźników. Do dóbr nieruchomych, należących do prepozyta, zaliczono folwark w Starej Pilicy, staw i sadzawkę z korytem, 7 ogrodów oraz dwie łąki. Istotnym przywilejem prepozyta pilickiego było także prawo prowadzenia wolnego wyrębu w okolicznych lasach ${ }^{29}$. Tak bogate uposażenie prepozytury ustanowionej przez biskupa Oleśnickiego, stojącego w opozycji wobec Pileckiego, skłania do refleksji nad wspomnianym wcześniej husytyzmem, któremu rzekomo ulegać mieli członkowie stronnictwa iuniores i konfederaci Spytka z Melsztyna. W świetle przytoczonych źródeł zarzut herezji w stosunku do osoby Jana z Pilczy wydaje się być dalece bezpodstawnym. Wspomagał on rozwój Kościoła na ziemiach znajdujących się pod jego zarządem. Taki był również powód podjęcia zabiegów o powołanie prepozytury w Pilicy. Niewykluczone, że motywem tego działania była właśnie chęć rozwinięcia na wyższym poziomie życia religijnego mieszkańców oraz posługi duszpasterskiej kleru ${ }^{30}$. Współpraca Jana ze swą siostrą w kwestii uposażenia prepozytury

27 Zbiór dokumentów katedry i diecezji krakowskiej (dalej ZDK), 2, wyd. S. Kuraś, Lublin 1973, nr 270.

28 Tamże, nr 309; H. Błażkiewicz, Pilica: Zarys dziejów miejscowości, Kraków 1992, s. 145.

29 ZDK, 2, Lublin 1973, nr 309; H. Błażkiewicz, dz. cyt., s. 145.

30 Tamże, s. 147. 
pilickiej świadczyć może także o wspólnych poglądach rodzeństwa i prawdopodobnie dobrych stosunkach, jakie ze sobą utrzymywali.

W roku 1450 Jan z Pilczy potwierdził szpitalowi świętej Jadwigi w Stradomiu nadanie czynszu z bocheńskiej żupy solnej. Również ta fundacja Pileckiego stanowiła powtórzenie uposażenia dokonanego przez jego matkę - królową Elżbietę. W dokumencie, zawierającym warunki uposażenia, Jan zastrzegł sobie możliwość opieki i sprawowania zarządu, jak również prawo patronatu nad szpitalem ${ }^{31}$. Gest ten stawia Pileckiego w roli kontynuatora programu ideologiczno-społecznego swej matki.

Po objęciu urzędu wojewody krakowskiego, Jan z Pilczy uposażył na swych dobrach również kościół i parafię w Chmielniku ${ }^{32}$. Jej obsada otrzymała wówczas wolność korzystania z zasobów tamtejszych rzek i lasów oraz pastwisk. Duszpasterze mogli także używać młynów oraz posiadali prawo do przyjmowania ofiar stołowych. Pleban parafii miał otrzymywać od kmieci żyto i owies w liczbie kłody od łanu ziemi. Ponadto Jan nadał kościołowi dwa rolne łany ${ }^{33}$. Innym uposażonym przez Jana kościołem była świątynia w Borku Starym, której nadał jeden łan ziemi we wsi Nowy Borek ${ }^{34}$. Daje to podstawy, żeby twierdzić, iż Pilecki był żywo zainteresowany wzmacnianiem Kościoła na jego najniższych szczeblach. Uposażanie lokalnych parafii nie przynosiło takiej popularności, jak fundacje klasztorne, co wskazywać może częściowo na motywację Pileckiego, któremu zależało na sprawnym funkcjonowaniu mniej eksponowanych jednostek administracji kościelnej. Podobnym przykładem jest także uposażenie przez Jana z Pilczy kościoła parafialnego w Kosinie ${ }^{35}$.

Inną istotną fundacją kościelną Jana z Pilczy było ustanowienie w 1454 r. w Tyczynie mansjonarskiego kolegium przy kościele parafialnym. Było ono poświęcone Najświętszej Marii Pannie i składało się z trzech członków (wikariuszy) oraz rektora. Kolegium to zostało przez Pileckiego uposażone dochodem 22 grzywien rocznego czynszu, pochodzącego ze wsi Budziwój ${ }^{36}$. Fakt ten postrzegać należy jako przejaw żywej troski o edukację duchową i przyszłość Kościoła, a także dowód przywiązania do kultu Maryi, rozpowszechnionego w tym czasie wśród małopolskiej szlachty. W 1466 r. Jan z Pilczy ufundował budowę nowego, murowanego kościoła dla Tyczyna ${ }^{37}$. W połączeniu z obrazem zabiegów gospodarczych, jakie czynił on dla tego miasta, rysuje się rodzaj specjalnej troski, jaką darzył je Pilecki. Odpowiednie zarządzanie i fundacje na rzecz miasta, skutkowały prawdopodobnie zwiększaniem się liczby mieszkańców i odwiedzających je kupców, co miało bezpośredni wpływ na rozwój tego ośrodka. W kontekście działalności innych członków stronnictwa młodoszlacheckiego na rzecz rozwoju sieci parafialnej można również zauważyć ich przywiązanie do tego rodzaju aktywności. Warto

31 ZDK, 2, Lublin 1973, nr 546; Korespondencja żupnika krakowskiego Mikołaja Serafina z lat 1437-1459, wyd. W. Bukowski, T. Płóciennik, A. Skolimowska, Kraków 2006, s. 99.

32 ZDM, 5, 1970, nr 1431.

33 Tamże.

34 A. Festnacht, Słownik historyczno-geograficzny ziemi sanockiej w średniowieczu, Brzozów 1991, s. 49.

35 F. Sikora, Pilecki (Granowski) Jan h. Leliwa (ok. 1405-1476), Polski Słownik Biograficzny, t. 26, Kraków Wrocław 1981, s. 258.

36 F. Kiryk, S. Mateszew, dz. cyt., s. 52.

37 Tamże, s. 67. 
przytoczyć w tym miejscu choćby przykład kościoła w Batorzu, ufundowanego razem z działającą przy parafii szkołą, przez Andrzeja Tęczyńskiego ${ }^{38}$.

Analizując działalność fundacyjną Jana z Pilczy, należy wspomnieć o księgozbiorze, jaki gromadził w swej pilickiej rezydencji. Zagadnienie odtworzenia jego zawartości może służyć jako temat oddzielnych badań, jednak warto odnotować w tym miejscu przede wszystkim fakt istnienia biblioteki na zamku w Pilicy. Informuje o niej w swych zapiskach z początku XVI w. Biernat z Lublina, wybitny humanista i pisarz, który przez niemal dwadzieścia lat pełnił funkcję nadwornego lekarza, kapelana i sekretarza pilickiego zamku. Jego mecenasem był wnuk Jana z Pilczy - również Jan (III). Wspominając pobyt na jego dworze, Biernat zapisał, iż spędzał tam wiele czasu na czytaniu ksiąg, których wiele było na zamku w Pilicy, co sprzyjać miało pracy Biernata ${ }^{39}$. Wśród wydawnictw, z którymi się tam zetknął, należy wymienić choćby Historię o Trzech Królach (Historia Trium Regum) Jana z Hildesheimu. Z dużą dozą prawdopodobieństwa można stwierdzić, iż Biernat korzystając z pilickiego księgozbioru, miał okazję zetknąć się także z dziełami zebranymi przez dziada swego opiekuna i mecenasa ${ }^{40}$. Jest bowiem mało prawdopodobne, aby sam Jan III Pilecki zdołał zgromadzić bibliotekę, którą Biernat mógłby opisywać z takim zachwytem. Wniosek ten świadczyć mógłby o poziomie intelektualnym kasztelana krakowskiego Jana z Pilczy i jego potrzebie kontaktu z kulturą. O uwadze, jaką Pilecki poświęcał poszerzaniu wpływów kultury łacińskiej w swoim środowisku, świadczyć może także fakt zatrudnienia Włocha - Jana Fabianiego - na stanowisku swego sekretarza ${ }^{41}$. Zważając na to, że w połowie XV wieku przysposabianie obcokrajowców jako swych współpracowników nie było zjawiskiem popularnym w gronie świeckich możnych, można uznać, iż Pilecki wspierał ideę czerpania z kontaktów międzypaństwowych również w węższym, rodowym wymiarze. Czynniki te dopełniają obrazu Jana z Pilczy jako człowieka światłego i ambitnego, który osiągnąwszy sukces polityczny nie zapominał także o rozwoju kultury materialnej i duchowej w swym otoczeniu. Cechę tę odziedziczyli po nim również jego potomkowie, wspierając polski humanizm w epoce odrodzenia.

Mimo, że sam Jan z Pilczy nie ufundował od podstaw prawdopodobnie żadnego klasztoru, to wiadomo, że jego współtowarzysze z obozu iuniores zdołali wykazać się w tej sferze bogatą działalnością. Głównymi przyczynami podejmowania tego rodzaju inicjatyw przez możnych były pragnienia dewocyjne oraz funkcje kommemoracyjne, jakie dane zgromadzenie pełnić miało względem osoby swego fundatora ${ }^{42}$. Obecność klasztoru determinowała także rozwój oświaty i edukacji na danym terenie. Nie pozostawała ona bez wpływu na rozwój kultury, między innymi za sprawą prowadzonych przez zakonników szkół przyklasztornych, bibliotek i skryptoriów ${ }^{43}$. Wszystkie te czynniki sprawiały, iż reprezentanci stanu szlacheckiego często ustanawiali nowe fundacje klasztorne i uposażali już istniejące. Nie sposób dostrzec wspólnych

\footnotetext{
38 J. Kurtyka, Tęczyńscy. Studium z dziejów polskiej elity możnowładczej w średniowieczu, Kraków 1997, s. 498; ZDM, 3, nr 849.

39 „, Aetas ista potissimum in legendo mihi decursa, diutie bona librorum copia et quies in Pylca”. Zob. S. Grzeszczuk, Jam byt Biernat z Lublina (Wstęp do wydania Ezopa Biernata z Lublina), Kraków 1997, s. 13-15.

40 Tamże, s. 16.

$41 \quad$ F. Sikora, dz. cyt., s. 258.

42 Z. Zyglewski, Klasztorne fundacje możnowładztwa koronnego w okresie jagiellońskim. Zarys problematyki, w: Klasztor w społeczeństwie średniowiecznym i nowożytnym, red. M. Derwich, A. Pobóg-Lenartowicz, Opole Wrocław 1996, s. 134.

43 Tamże, s. 140-141.
} 
cech łączących członków stronnictwa w tej dziedzinie działalności, jak to miało miejsce w przypadku niektórych innych rodów w tym czasie ${ }^{44}$. Najbardziej imponująco prezentuje się w tym kontekście dorobek fundacyjny Jana Hińczy z Rogowa. Jego dwiema najsłynniejszymi fundacjami były klasztory: kanoników regularnych w Krzepicach oraz bernardynów w Kole ${ }^{45}$. Założenie klasztoru krzepickich kanoników jest szczególnie interesujące w kontekście politycznej i osobistej sympatii Hińczy do królowej Zofii Holszańskiej. Życzeniem Rogowskiego przy zakładaniu klasztoru było, aby zakonnicy żarliwie modlili się za duszę królowej. O wadze, jaką miała dla niego ta intencja, świadczy fakt podjęcia jej przed prośbą o modlitwę za siebie i swą rodzinę ${ }^{46}$. Ponadto Hińcza dokonał wielu nadań na rzecz wspólnot klasztornych. Do najważniejszych należy zaliczyć przekazanie dochodów z żup na utrzymanie krakowskich bernardynek św. Agnieszki, a także uposażenie klasztoru bernardynów w Krakowie, kanoników regularnych w Mstowie, bożogrobców z Miechowa oraz dominikanów Św. Trójcy w Krakowie ${ }^{47}$. Z tymi ostatnimi do niedawna łączono także działalność dobroczynną rodziny Tęczyńskich, jednak relacje tego klasztoru z rodem rozwinęły się dopiero u schyłku XV stulecia, co wyklucza możliwość istnienia jego związków z osobą Andrzeja Tęczyńskiego ${ }^{48}$. Wśród uposażanych przez iuniores klasztorów znajdowali się także bernardyni z Opatowa, których dobrodziejami byli Dziersław i Jan Rytwiańscy, odpowiedzialni także za ufundowanie w sandomierskiej kolegiacie altarii świętych Młodzianków ${ }^{49}$.

Uposażenie łączyło się często również z ustanawianiem lub przenoszeniem prawa patronatu. Tak było między innymi w przypadku kościoła parafialnego w Koniuszy, którego jednym z patronów był teść Jana z Pilczy, Piotr Kurowski ${ }^{50}$. W 1460 r. zapisał on także 20 grzywien z rocznego czynszu wsi Brzozowa mansjonarzom z Kurowa ${ }^{51}$. W tym samym roku doprowadził do uposażenia lubelskich dominikanów ${ }^{52}$. Krakowscy augustianie natomiast, byli beneficjentami nadań Mikołaja Lanckorońskiego z Brzezia ${ }^{53}$. Wspomnianych altarystów sandomierskich bracia Rytwiańscy uposażyli między innymi sumą 40 grzywien czynszu pochodzącego z cła miejskiego. Przekazali też na ich rzecz cenne naczynia liturgiczne, szaty oraz trójtomową postyllę, mszał i dwutomową, pergaminową Biblię, przenosząc jednocześnie prawo patronatu nad altaria na Wydział Sztuk Wyzwolonych Uniwersytetu Krakowskiego ${ }^{54}$.

\footnotetext{
44 U schyłku wieku XV występowała zależność rodzinna w kwestii fundacji klasztornych. Poszczególne zgromadzenia wspierane były przez wybrane rodziny. Zjawisko to dotyczyło między innymi Oleśnickich, Oporowskich czy Koniecpolskich. Zob. Z. Zyglewski, dz. cyt., s. 139.

45 B. Czwojdrak, Rogowscy herbu Działosza - podskarbowie królewscy, Katowice 2002, s. 151-156; Taż, Zofia Holszańska. Studium o dworze i roli królowej w późnośredniowiecznej Polsce, Warszawa 2012, s. 139.

46 Tamże.

47 Taż, Rogowscy..., s. 156-158.

48 M. Zdanek, O zwiąkach rodziny Tęczyńskich z konwentem dominikanów krakowskich, w: Narodziny Rzeczpospolitej. Studia z dziejów średniowiecza i czasów wczesnonowożytnych, red. W. Bukowski, T. Jurek, t. 1, Kraków 2012, s. 456.

49 W. Fałkowski, Rytwiański Dziersław h. Jastrzębiec (1414-1478), Polski Słownik Biograficzny, t. 33, Wrocław Warszawa Kraków 1991-1992, s. 587.

50 ZDM, 5, nr 1318.

51 Stownik historyczno-geograficzny województwa lubelskiego, wyd. S. Kuraś, Warszawa 1983, s. 40.

52 Tamże, s. 133.

53 F. Kiryk, Lanckoroński Mikołaj h. Zadora..., s. 446.

54 W. Fałkowski, Rytwiański Dziersław..., s. 587.
} 
Egzemplarz Biblii, Dziersław z Rytwian zapisał w swym testamencie kapitule krakowskiej ${ }^{55}$. Popularnością wśród fundatorów cieszyły się wówczas także szpitale, takie jak ten pod wezwaniem św. Ducha w Krakowie, uposażony przez Jana Hińczę z Rogowa, który swoją działalność zwieńczył sfinansowaniem budowy kaplicy Hińczów w katedrze krakowskiej ${ }^{56}$.

Aktywność przedstawicieli stronnictwa iuniores, w tym również Jana z Pilczy, na polu działalności fundacyjnej i gospodarczej stanowiła znaczący element realizacji programu ideowo-politycznego ugrupowania. Jej charakterystyka stanowi istotne uzupełnienie obrazu dziejów frakcji młodoszlacheckiej, powstałej na fundamencie aktu konfederacji Spytka z Melsztyna z 1439 r. Pogłębianie badań w tym zakresie zbliżać może do pełniejszego ukazania życiorysów poszczególnych członków ugrupowania. W tym kontekście syntetyczna prezentacja działalności jednego z ważniejszych członków obozu oponentów Zbigniewa Oleśnickiego, kasztelana krakowskiego Jana z Pilczy, skłania do rozwoju rozważań na temat rzeczywistej postawy tej części przedstawicieli późnośredniowiecznego możnowładztwa Korony Królestwa Polskiego, ugrupowania, któremu, jak dotąd, poświęcano we współczesnej historiografii niewystarczającą uwagę.

\section{Cracow castellan - Jan from Pilcza economic and chantry activity. Profile against a background of chosen Iuniores faction members activity Summary}

The article presents the most important examples of castellan Jan from Pilcza economic and foundational activity in the context of other Iuniores faction members achievements. The text elaborates endowments and ways of managing the lands by Jan from Pilcza and members of the young nobles party. It contains also some observations about common points of Iuniores actions - groups known as the main part of the opposition against bishop Zbigniew Oleśnicki. Recognition of these activities profiles is helpful in better understanding the ideological and political attitude of medieval Crown of Polish Kingdom noble elite representatives, who were participants of Spytko from Melsztyn confederetion.

The Jan from Pilcza biography is an example of political and social advancement in times of Władysław III and Kazimierz Jagiellończyk reigns. His economic activity had been mainly based on profits from his lands and developing, inter alias, trade markets. Privileges which he dedicated for Tyczyn and Łańcut confirm the observed trend. Also mining was an economy branch developed in described region by Jan from Pilcza. The mentioned activity had a positive impact on defensive capability of Crown of Polish Kingdom. Jan from Pilcza's economic activities, such as salt-mining organizing, could be viewed as similar to other iuniores. In that context it is necessary to highlight that iuniores chantry actions, endowments and a lot of connections between them and catholic Church are denying the thesis about Hussitism among this political faction representatives.

Keywords: Jan from Pilcza, Iuniores, nobles, middle ages, endowments

Nota o Autorze: Jan Szyrwiński - doktorant i absolwent Instytutu Nauk Historycznych Wydziału Nauk Historycznych i Społecznych UKSW. W swych badaniach podejmuje problematykę dziejów średniowiecznego możnowładztwa oraz historii politycznej.

55 Tamże.

56 B. Czwojdrak, Rogowscy..., s. 160-165. 